\title{
Combating the Spread of COVID-19 Through Community Participation
}

\author{
Lalgoulen Khongsai ${ }^{1}$ (D) • T. S. Shanghring Catherine Anal ${ }^{2} \cdot$ Rapheileng A.S. $^{3} \cdot$ Tomba Singh Kh. $^{3}$. \\ Md. Kheiruddin Shah ${ }^{4}$. Digvijay Pandey ${ }^{5}$
}

Published online: 21 July 2020

(C) Springer Nature Switzerland AG 2020

\begin{abstract}
India has a vast population with a weak public health system, which is vulnerable to the COVID-19 pandemic. Economically and physically, India is in a state of considerable risk of the COVID-19 pandemic. Community participation through various measures is the only way to limit the spread of the virus. The present study investigates the possibility of social intervention and involvement in controlling the pandemics and its cascading effect. The study identifies 5 ' $\mathrm{S}$ ', namely, segregation, sensitization, social fencing, solidarity, and social services, to control the disease through people's participation that could throw insights into controlling the virus and minimizing the aftershock of the pandemic.
\end{abstract}

Keywords COVID-19 $\cdot$ Pandemic $\cdot$ Community participation $\cdot$ Social $\cdot$ India $\cdot$ Spread $\cdot$ Symptoms $\cdot$ Asymptomatic

\section{Introduction}

Coronavirus is a large family of viruses causing illness in animals or humans. Coronavirus is known to cause human respiratory infections ranging from the common cold to more severe diseases such as Middle East respiratory syndrome (MERS) and severe acute respiratory syndrome (SARS). The most recently discovered coronavirus causes coronavirus disease (COVID-19), which was unknown before the outbreak began in Wuhan, China, in December 2019 (Q\&A on coronaviruses (COVID-19) n.d.). It was declared a global pandemic on 11th March 2020 (India ramps up efforts to contain the spread of novel coronavirus 2020). Even though the low fatality rate of COVID-19, it has killed

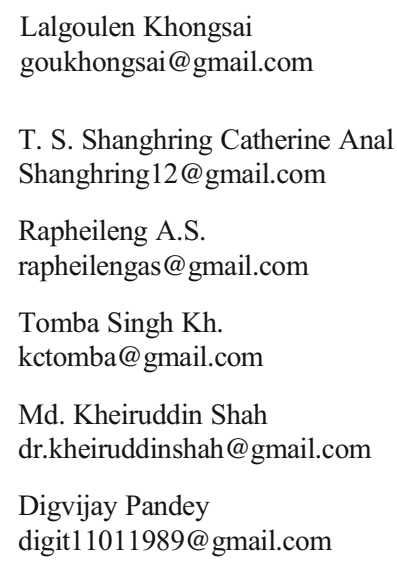

more people than SARS and MERS combined (Mahase 2020).

The World Health Organisation (WHO) discovered that most of the COVID-19-infected person had shown a symptom such as fever, tiredness, and dry cough whereas some patients had aches, pains, nasal congestion, runny nose, sore throat, or diarrhoea which is usually mild and begins showing the symptoms gradually. They also found that few infected people are asymptomatic, with a recovery rate of roughly $80 \%$ without special treatment. Only 1/6 of the COVID-19-infected people become complicated with shortness of breathing, but they established that the diseases are fatal for aged people with a history of high blood pressure, cardiac, and diabetic (Q\&A on coronaviruses (COVID-19) n.d.).

1 Department of Commerce, Manipur University, Canchipur, Imphal, Manipur, India

2 Manipur Institute of Management Studies, Manipur University, Canchipur, Imphal, Manipur, India

3 Department of Commerce, Manipur University, Canchipur, Imphal, Manipur, India

4 Department of Commerce, Dhanamanjuri University, Imphal, Manipur, India

5 Department of Technical Education, IET, Lucknow, Uttar Pradesh, India 
A small human oral droplet contains millions of coronavirus claims (Nikam et al. 2020). van Doremalen et al. (2020) found that the virus lives the longest on plastic and steel, surviving for up to $72 \mathrm{~h}, 4 \mathrm{~h}$ in copper, and $24 \mathrm{~h}$ in cardboard. They observed and confirmed that when the virus suspended into small droplets (aerosols, which are smaller than $5 \mu \mathrm{m}$ ) can survive in the air for about half an hour before settling down on the surface and stays there for hours. Centre for Diseases Control and Prevention, a United States Department of Health and Human Services, reported that COVID-19 spread mainly through close contact from human to human respiratory droplets of an infected person. Furthermore, a new study by Zhang et al. (2020) confirms that COVID-19 could spread through the oral faecal route and classify human virus carriers as symptomatic and asymptomatic, both of which have Da high chances of spreading the virus.

Singhal et al. (2020) reveal that homeless and slum dwellers living in congregate settings without regular access to basic hygiene and sanitation could be the main route of spreading the virus. They recognize older people and children as vulnerable groups. On the other-19hand, Borah et al. (2020) identify five prominent groups, namely, children, women, migrants, daily-wage earners, and self-employed individuals as the vulnerable groups to the economic and health shocks of COVID-19 pandemics. In the light of this revelation, Borah et al. (2020) find it essential to identify the geographic concentration and the number of migrant workers to ensure that the relief efforts focusing on this vulnerable group can be better planned and targeted.

Thacker (2020) quotes Raman R Gangakhedar, the Chief Epidemiologist of the Indian Council of Medical Research (ICMR), that $80 \%$ of the people infected with coronavirus in India are asymptomatic. This revelation has put India in grave danger because the testing rate in India per thousand is very low compared with other countries. We have not done enough tests to put us at mental peace. For instance, Dubey (2020) reported in Business Standard that India has one of the lowest tests per million with a mere 1973 person test per million which is only half of the test that Brazil has done, whereas Spain has done 60,000 tests per million and they are on the road to recovery. As per ICMR data as on 17th June 2020, there are only 953 (699 government and 254 private) operational testing laboratories in India which are inadequate to accommodate the testing service of the massive population in the country. It is physically and economically not viable for a country like India to test every citizen to confirm the total numbers of COVID-19-infected persons.

Non-availability of medicines, improper treatment, easy human to human transmission, insufficient testing laboratories, low test rate, poor public health system, and a high number asymptomatic infected person pose a significant threat to the country. So the question here is how do we prevent ourselves from the virus? What are the precautions to control the spread of the viruses? What action can be taken by the government, the public health system, and the community in limiting the spread of COVID-19? What are the economic and health-related remedial measures at the community level? Thus, the global community needs to take additional efforts in controlling the spread of viruses until vaccines and antidote are available. The significance of community participation, understanding, and behaviour change was highlighted by Golechha (2020) in his study. The authors of this paper attempt to develop action-oriented principles that could assist in curbing the spread of COVID 19 to a great extent. The techniques propagated by the authors can be employed at the community level with a poor public health system where there is a high chance of community transmission.

\section{Status of COVID-19 in India}

India reported its first COVID-19 cases on 30th January 2020 in the state of Kerala, who has a history of travelling to Wuhan, China (Vara 2020). According to the latest report of the Ministry of Health and Family Welfare (MoHFW) on 18th June 2020 (6:50 PM), the total COVID confirmed cases in the country are 366,946 . The total number of recovered cases is 194,325 , and the total death is 12,237 . The mortality rate stands at $3.33 \%$ which is low compared with other most affected countries like the USA, Brazil, and the UK which are $5.53 \%, 4.95 \%$, and $14.08 \%$, respectively ('WHO Coronavirus Disease (COVID-19) Dashboard' 2020). The recovery rate reported by livemint as on 26th May 2020 was $41.6 \%$ which was already the highest so far in the world (Ray 2020). However, as on 18 th June 2020 , the recovery rate of COVID-19 patients in India stands at 52.95\%, which shows our commitment to controlling and treating COVID-19 patients.

\section{Future Prediction of COVID-19 in India}

Employing time series forecasting methods, Tiwari et al. (2020) predicted that COVID-19 confirm cases in India will reach 1,000,000 (1 million) by the end of May 2020 . Nevertheless, at the end of May 2020, the total confirms cases in the country were 182,143 , which is a relief comparing with the prediction made by Tiwari et al. (2020). On the other hand, a group of researchers in Singapore have prepared a mathematical model called SIR (susceptible infected recovered) to predict when the end date of COVID-19 pandemic for different countries (Fig. 1). This model predicted that India would see a $97 \%$ decline by May 22nd, 2020, and estimated that $99 \%$ of Indians will be cured by June 1 and expected that the coronavirus will be eliminated by 26th July 2020 . However, as 
Fig. 1 COVID-19 progress graph for India based on the SIR model (Ghosh 2020). Source: https:// www.indiatoday.in/coronavirusoutbreak/story/when-will-covid19-outbreak-end-in-indiaresearchers-risk-a-may-date1671533-2020-04-27

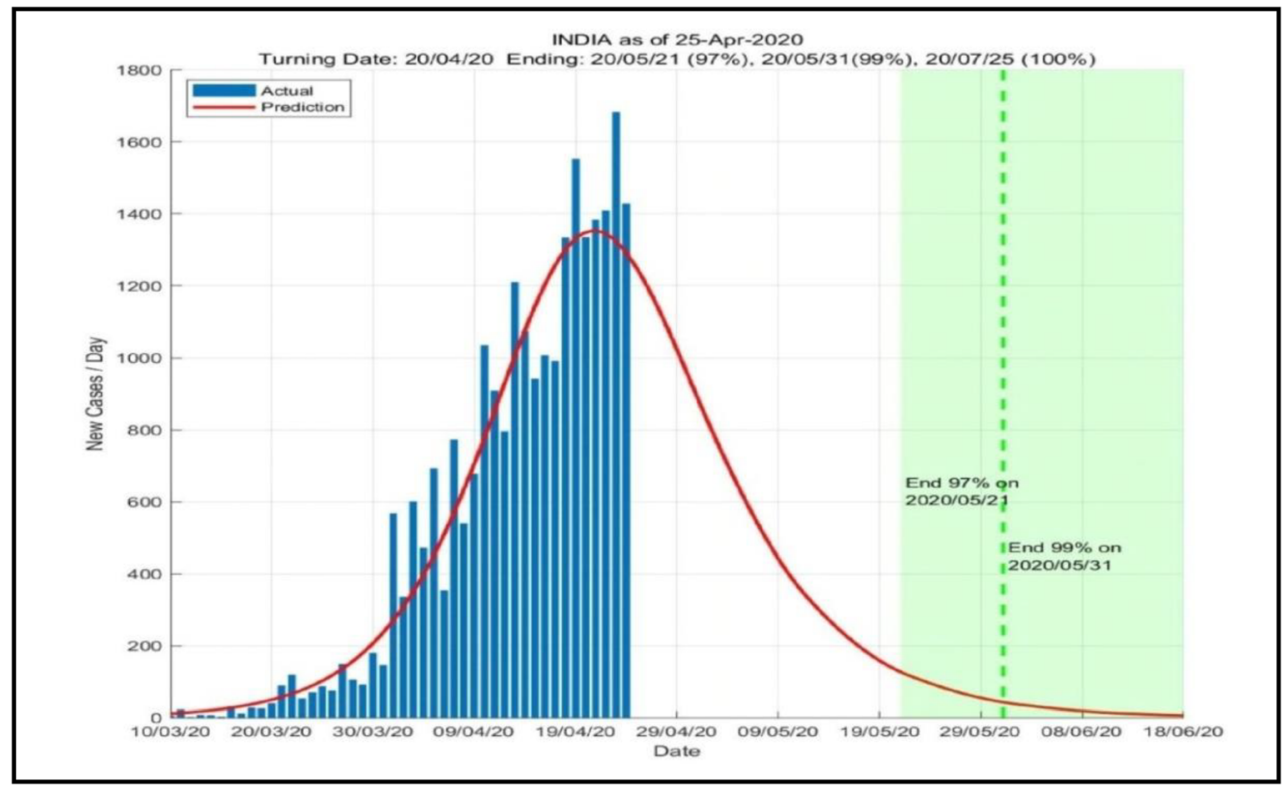

of June 18 th, the recovery rate is only $52.95 \%$, which does not hold for India. However, the increasing rate of recovery in India is promising and giving hope to the people.

Furthermore, based on 5-day moving average (Fig. 2), India has succeeded in reducing the growth rate of COVID19 cases from 24.3 to $3.8 \%$ from pre-nationwide lockdown from 18th March 2020 to post-nationwide unlock phase 1. Nevertheless, during the last few days, cases reported in India are above 10,000 , putting it in a considerable risk of community transmission.

\section{Impact of COVID 19}

Singhal (2020) confirms that COVID-19 spread very fast and has lower fatality than MERS and SARS, but he is uncertain of the global impact it will create in the future. Bobdey et al. (2020) have rightly concluded that pandemics' impact is far from the imagination as it causes a loss of human lives and threatens the economic set-up of the infected counties. They underline the importance of being vigilant, prepared, and contained, and make any efforts to prevent the spread of the virus in the future because COVID-19 has impacted every country in different ways except the facemask manufacturers who has the last laugh. The economic impact of COVID-19 is more severe than SARS or MERS (Scott 2020). The main concern of the government will be to save not only lives but also the livelihood. Kumar (2020) has strongly advocated on the dangers of the pandemic second wave from the experience of Spanish flu which has caused more death in the second round. He predicted that the worse is yet to come. So the global community needs to be well-prepared to face any
Fig. 2 Analysis of daily cases of COVID 19 case growth rate (based on 5-day moving average). Source: Ministry of Health and Family Welfare, Government of India (Graph by Soham Sen, The print)

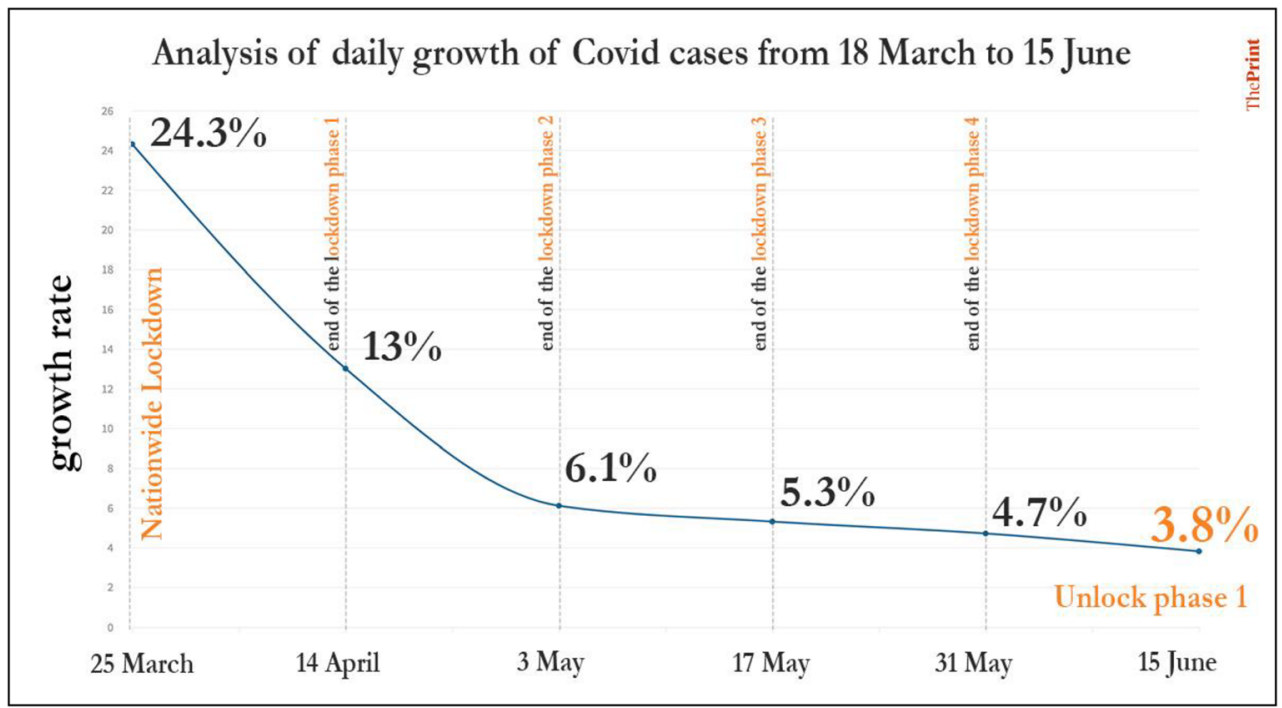


health and economic consequences to avoid economic depression. The Asian Development Bank is worried that there is a tremendous decline in developing nations of Asia through various channels, which include domestic demands, reduction in tourism and business travels, disruption in linkages between production, consumption, and distribution, and health impact (Abiad et al. 2020).

\section{Management of COVID-19 Through Community Participation}

Concerted efforts by the government and the community can reduce the transmission of COVID-19. The best strategy to limit the transmission on a large scale is quick identification of COVID-19-infected people through extensive testing, prevention through a mass awareness campaign, preventing the old and vulnerable people, isolating the COVID-19 patients, rapid diagnosis, and tracing the contacts of the patients for quarantine and follow-up. With the support of the local community, the government can play a pivotal role in controlling the spread of the diseases. They can act as a watchdog in reporting a suspected case with travel history, assisting the government in isolating the travellers, and educating the illiterate rural mass through Information Education and Communication (IEC). The Government of India has done a tremendous job by announcing countrywide lockdown and special economic packages during the COVID pandemic to save lives and livelihoods. The global community viewed this as a very successful and wise decision to prevent the virus spread and save the country's economy.

Recognizing the severity of the pandemic and unavailability of vaccine and antiviral drugs, we have developed ' $5 \mathrm{~S}$ ', namely, segregation, sensitization, social fencing, solidarity, and social service to control the spread of COVID-19 at the community level.

\section{Segregation}

The first cases COVID-19 in India have a travel history of China. Thus, Wilder-Smith et al. (2020) have conceded for the need of the medical community and policy-makers to enforce containment of foreign travellers. They highlighted the need for containment of the infected person through early case detection, quick isolation of the infected person, and an infected person's immediate quarantine. They further added to implement community quarantine if institutional quarantine is not feasible. They advocated the segregation of travellers and keeping them in isolation until the window period of 14 to 28 days at the government and community quarantine centres. Keeping the travellers under the observations of medical experts might seem costly but will have a significant impact on containing the spread of the virus in the long run.

Moreover, community leaders and social organizations can play a vital role by segregating the vulnerable people, especially the senior citizens and children, from associating with travellers. Segregating the travellers from the public and the vulnerable people can be useful in delaying the spread of the virus among the community and reduce the peak of its spread. The segregation will minimize the size of the outbreak and impact on the public health system until an effective vaccine becomes available.

\section{Sensitization}

He et al. (2020) advocated that controlling sources of infection, protecting the susceptible people, and cutting off the transmission as the best alternative to deal with COVID-19. Furthermore, the WHO also advises that the most effective ways to protect ourselves from COVID-19 are to frequently wash our hands, cover our mouth with bend elbows or tissue,

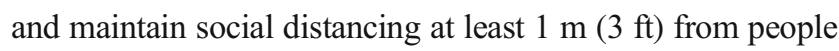
who are coughing and sneezing. Social distancing measures and personal etiquettes like wearing a mask in public and frequent washing of hand will be achieved through public awareness and campaigns within the community level.

\section{Social Fencing}

Ban on mass political, educational, cultural, religious gatherings, encouraging home funerals, reducing the frequency of transport, and staying at home can only be achieved with the people's participation. Community intervention with sufficient transparency, trust, and people engagement is the need of the hour. The imposition of guidelines and standard operating procedures (SOP) must be focused, action-oriented, and non-coercive.

\section{Solidarity}

Moral and physical support to the infected person, their families, and frontline workers can be encouraged through proper awareness and education within the community level. Man is a social being. Social distancing can have a significant impact on people's psychological and mental health, especially the young, the elders, physically, and mentally challenged people. Thus, physical distancing should be enforce keeping into consideration and avoid emotional and social distancing. The community leaders should be aware of human affairs and social norms while enforcing COVID-19 control measures. The WHO Director-General's had been recently saying 'I 
want to say again, from my heart, that this is the time for solidarity, not stigma. There are worrying signs that the world is not hearing the call for unity and standing in unison with those at the epicenter in China who are saving lives and alleviating suffering. I again repeat: this is the time for solidarity, not stigma'.

\section{Social Services}

Philanthropic organizations, social workers, politicians, wealthy, and influential people have done a tremendous job in helping the poor during this COVID-19 outbreak. However, some politicians and social workers procured and hoarded huge amounts of essential commodities at a high price meant for their consumption and distribution as relief materials for their personal and political gains creating unnecessary demand-pull inflation, which gives immense hardship to the low-income population.

The Government of India under Pradhan Mantri Garib Kalyan Yojana announced Rs 1.7 lakh crore relief packages intending to provide a safety net for the vulnerable population and frontline medical personnel during the COVID-19 pandemic in kinds and cash. Community leaders can act as a watchdog by ensuring the relief materials reach the targeted population. Fair price shops and other local markets should be made operational by displaying the price list fixed by the concerned government. Furthermore, the distribution of relief materials by politicians and other influential people can be done transparently by local clubs and organisations through the proper arrangement and regulations. People should be encouraged to contribute through registered relief bodies like Prime Minister Relief Fund or Chief Minister Relief Fund. Physical and social audits are necessary while distributing relief materials. The economic packages announced by the government need a closed monitor to ensure that the benefit goes to the targeted people.

\section{Discussion}

The present study identifies the potential role a community can play in containing the spread of COVID-19 pandemic in the world and India. Speaking at the Global Online Conference on combating COVID-19 organized by Bennett University, Dale Fisher, Chair of the WHO Global Outbreak Alert and Response Network, highlighted the importance of social and community engagement in tackling transmission of COVID-19 (Tejonmayam 2020). Dale Fisher's comments are in tune with the previous studies of Blendon et al. (2008), Sangam (2020), Bedford et al. (2020), and Khandelwal (2020). The measures to control the spread of COVID-19 are varied, but the current study is limited only on the role played by community leaders and individuals at a grass-root level. The present study will shed light on the policy-makers in decision-making and implementations of programs and policies in tune with society's structure. The government must implement its programs and policies with the healthy participation of the people. The authors found that the local populations in different parts of the country were very callous about implementing the lockdown. The local people barricade their localities, restrict the funeral of COVID-19 patients, alienate health workers, block emergency health services, and strictly implement social distance in place of physical distance giving impetus to stigma within the community. Stigma within the community is a sign of lack of mass awareness among the people. The spread of COVID-19 pandemic is beyond health and will have a profound impact on the country's social and economic settings. Thus, intervention by the government through community involvement is the need of the hour. A future researcher can aim to curb the pandemic through a public health system with government-linked volunteers like Accredited Social Health Activist (ASHA), Village Level Workers (VLW), and Anganwadi.

\section{Compliance with Ethical Standards}

This article does not contain any studies with human participants or animals performed by any of the authors.

Conflict of Interest The authors declare that there is no conflict of interest.

\section{References}

Abdul Abiad, Mia Arao, Suzette Dagli, Benno Ferrarini, IIan Noy, Patrick Osewe, Jesson Pagaduan, Donghyun Park, and R P. (2020). The economic impact of the COVID-19 outbreak on developing Asia. https://doi.org/10.22617/BRF200096

Bedford, J., Enria, D., Giesecke, J., Heymann, D. L., Ihekweazu, C., Kobinger, G., et al. (2020). COVID-19: towards controlling of a pandemic. The Lancet, 395(10229), 1015-1018. https://doi.org/10. 1016/S0140-6736(20)30673-5.

Blendon, R. J., Koonin, L. M., Benson, J. M., Cetron, M. S., Pollard, W. E., Mitchell, E. W., Weldon, K. J., \& Herrmann, M. J. (2008). Public response to community mitigation measures for pandemic influenza. Emerging Infectious Diseases, 14(5), 778-786. https://doi.org/10. 3201/eid1405.071437.

Bobdey, S., Ray, S., Med, M., \& Search, S. (2020). Going viral- Covid19 impact assessment: a perspective beyond clinical practice. Journal of Marine Medical Society, 22(1), 1-5. https://doi.org/10. 4103/jmms.jmms.

Borah, A., Das, S., Dasgupta, A., Deshpande, A., \& Mahajan, K. (2020). Covid-19: Are we ready for the long haul ? - Part I. Retrieved from https://www.ideasforindia.in/topics/macroeconomics/covid-19-arewe-ready-for-the-long-haul-i.html.

Dubey, J. (2020). Covid-19 factoid: India's tests per $1 \mathrm{mn}$ people half as much as Brazil's. business standard. Retrieved from https://www. business-standard.com/article/current-affairs/covid-19-factoidindia-s-tests-per-1-mn-people-half-as-much-as-brazil-s120052300104_1.html. 
Ghosh, M. D. G. A (2020). India reduced Covid growth rate from $24.3 \%$ in pre-lockdown to $3.8 \%$ in unlock 1.0. The Print. Retrieved from $\mathrm{https}$ ://theprint.in/health/india-reduced-covid-growth-rate-from-243-in-pre-lockdown-to-3-8-in-unlock-1-0-govt-data/444058/.

Golechha, M. (2020). COVID-19, India, lockdown and psychosocial challenges: what next? International Journal of Social Psychiatry, 1-3. https://doi.org/10.1177/0020764020935922

He, F., Deng, Y., \& Li, W. (2020). Coronavirus disease 2019 (COVID19): what we know? Journal of Medical Virology, 2019, jmv.25766. https://doi.org/10.1002/jmv.25766.

India ramps up efforts to contain the spread of novel coronavirus. (2020). Retrieved April 27, 2020, from https://www.who.int/india/ emergencies/novel-coronavirus-2019.

Khandelwal, S. (2020). How to walk the talk on prioritising public health and nutrition. Retrieved from https:/www.ideasforindia.in/topics/ human-development/how-to-walk-the-talk-on-prioritising-publichealth-and-nutrition.html.

Kumar, D. (2020). The novel coronavirus ( COVID-19) need to find therapeutic solution. 6736(03), 9-10. https://doi.org/10.1056/ nejmoa2001316.Lu.

Mahase, E. (2020). Coronavirus: covid-19 has killed more people than SARS and MERS combined, despite lower case fatality rate (p. 1). TheBMJ. https://doi.org/10.1136/bmj.m641.

Nikam, R. M., Kapadnis, K. H., \& R. Y. B. (2020). A survey on epidemic growth of corona virus- covid-19 in global world: issues. Concern and. International Journal for Research in Applied Science \& Engineering Technology, 8(3), 938-941.

Q\&A on coronaviruses (COVID-19) (n.d.). Retrieved April 27, 2020, from https://www.who.int/news-room/q-a-detail/q-a-coronaviruses

Ray, A. (2020). India's recovery rate from COVID-19 rises to $41.6 \%$, highest so far. Retrieved June 20, 2020, from https://www.livemint. com/news/india/india-s-recovery-rate-from-covid-19-rises-to-41-6highest-so-far-11590475726213.html.

Sangam, V. (2020). Reducing the spread of covid-19: need for creative and long term measures. Economic and Political Weekly, 55(14).

Scott, J. (2020). The economic, geopolitical and health impacts of COVID-19. World Economic Forum, 565, 1-4 Retrieved from https://www.weforum.org/agenda/2020/03/the-economicgeopolitical-and-health-consequences-of-covid-19/.

Singhal, T. (2020). A review of coronavirus disease-2019 (COVID-19). The Indian Journal of Pediatrics, 87(4), 281-286. https://doi.org/ 10.1007/s12098-020-03263-6.

Singhal, T., Hoque, A., Shikha, F. A., Hasanat, M. W., Arif, I., Abu Bakar Abdul Hamid, ... World Health Organization (WHO) (2020). Asymptomatic carrier state, acute respiratory disease, and pneumonia due to severe acute respiratory syndrome coronavirus 2 (SARS-CoV-2): facts and myths. World Economic Forum, 395(1), 1-4. https://doi.org/10.1056/NEJMp2004361.

Tejonmayam, U. (2020). Community participation key to fighting pandemic: WHO expert | India news - times of India. The Times of India, pp. 1-25. Retrieved from https://timesofindia.indiatimes. com/india/community-participation-key-to-fighting-pandemicwho-expert/articleshow/75191075.cms

Thacker, T. (2020). Asymptomatic coronavirus cases. The Economic Times. Retrieved from https://economictimes.indiatimes.com/ industry/healthcare/biotech/healthcare/no-symptoms-in-80-ofcovid-cases-raise-concerns/articleshow/75260387.cms?from=mdr.

Tiwari, S., Kumar, S., \& Guleria, K. (2020). Outbreak trends of coronavirus (COVID-19) in India: a prediction. Disaster Medicine and Public Health Preparedness, 1-9. https://doi.org/10.1017/dmp. 2020.115.

van Doremalen, N., Bushmaker, T., Morris, D. H., Holbrook, M. G., Gamble, A., Williamson, B. N., Tamin, A., Harcourt, J. L., Thornburg, N. J., Gerber, S. I., Lloyd-Smith, J. O., de Wit, E., \& Munster, V. J. (2020). Aerosol and surface stability of SARS-CoV-2 as compared with SARS-CoV-1. New England Journal of Medicine, 382(16), 1564-1567. https://doi.org/10.1056/NEJMc2004973.

Vara, V. (2020). Coronavirus in India: how the Covid-19 pandemic affects India. Retrieved April 28, 2020, from https://www. pharmaceutical-technology.com/features/coronavirus-affectedcountries-india-measures-impact-pharma-economy/.

When will Covid-19 end in India and elsewhere? Researchers risk a May date - coronavirus outbreak news (n.d.). Retrieved April 27, 2020, from https://www.indiatoday.in/coronavirus-outbreak/story/whenwill-covid-19-outbreak-end-in-india-researchers-risk-a-may-date1671533-2020-04-27.

WHO Coronavirus Disease (COVID-19) Dashboard (2020). https://doi. org/10.1201/b22185-42.

Wilder-Smith, A., Chiew, C. J., \& Lee, V. J. (2020). Can we contain the COVID-19 outbreak with the same measures as for SARS? The Lancet Infectious Diseases, 3099(20). https://doi.org/10.1016/ S1473-3099(20)30129-8.

Zhang, Y., Xu, J., Li, H., \& Cao, B. (2020). A novel coronavirus (COVID-19) outbreak. Chest, 157(4), e99-e101. https://doi.org/ 10.1016/j.chest.2020.02.014.

Publisher's Note Springer Nature remains neutral with regard to jurisdictional claims in published maps and institutional affiliations. 